\title{
EFFECT OF CORPORATE SOCIAL RESPONSIBILITY ON INVESTMENT EFFICIENCY OF QUOTED OIL AND GAS FIRMS IN NIGERIA
}

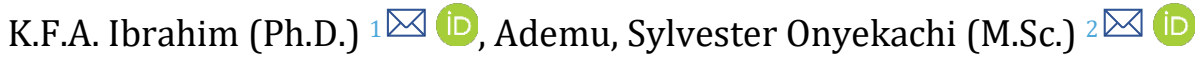 \\ 1,2 Department of Accounting, University of Abuja, Nigeria.
}

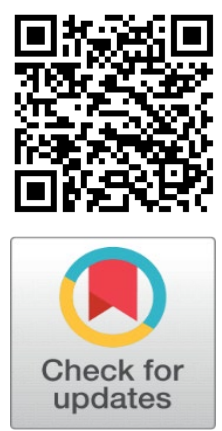

Received 16 October 2021

Accepted 2 November 2021

Published 30 November 2021

\section{CorrespondingAuthor}

K.F.A. Ibrahim (Ph.D.),

kamaludeen.ibrahim@uniabuja.edu.ng

DOI

10.29121/granthaalayah.v9.i11.2021 .4258

Funding: This research received no specific grant from any funding agency in the public, commercial, or not-for-profit sectors.

Copyright: (C) 2021 The Author(s). This is an open access article distributed under the terms of the Creative Commons Attribution License, which permits unrestricted use, distribution, and reproduction in any medium, provided the original author and source are credited.

\section{ABSTRACT}

This study examined effect of corporate social responsibility (CSR) on investment efficiency of quoted oil and gas firms in Nigeria. The study employed Ex post facto research design. The sample size of seven (7) oil and gas firms was derived from the population of the quoted twelve (12) oil and gas firms in Nigeria. Judgmental approach was employed during the sampling procedure. The study used secondary data sourced from the annual reports of the quoted oil and gas firms in Nigeria Stock Exchange fact books of official lists covering a ten-year period (2010-2019). The study employed Multiple Regression Model as the technique of data analysis with the aid of SPSS 23 statistical software. Analysis of findings showed that CSR charitable donation expenditure, CSR expenditure on education and CSR societal expenditure reveal significant relationship with investment efficiency of oil and gas firms in Nigeria. Nevertheless, CSR health expenditure and CSR environmental expenditure show insignificant effect on investment efficiency of oil and gas firms in Nigeria. The study also reveals that there is significant relationship between CSR sports expenditure and investment efficiency of oil and gas firms in Nigeria. With respect to the findings, the study recommends that the oil and gas firms should boost and monitor their CSR charitable donation expenditure, CSR on health expenditures, CSR environmental and CSR sport expenditures and observe them closely since they reveal negative effect. The study also recommends that CSR expenditure on education and CSR societal expenditure should be upheld and sustained since they reveal significant positive effect on investment efficiency of oil and gas firms in Nigeria.

Keywords: Corporate Social Responsibility, Investment Efficiency, Quoted Oil, Gas Firms

\section{INTRODUCTION}

The truth is that oil has performed a key role pertaining to degradation of the natural environment which led to monocultural economy in Nigeria, still we have to accept that oil and gas sector in Nigeria has brought "better than harm" in Nigeria at large Ugwukah and Ohaja (2016) even though there are huge expenditures tangled with participating in social responsibility that might distress the company's performance Ishola and Ishola (2019). Petroleum companies are chief sectors in the energy market and they take up powerful responsibilities in the international industry as the world's major fuel sources Vassiliou (2018). This sector is classified in triple: upstream, the commerce of oil and gas exploration and production; midstream, transportation and storage; and 
downstream, that comprises refining and marketing of oil and gas Vassiliou (2018).

Nevertheless, the above activities by the firms are not performed in a vacuum; there must be an environment where these operations are carried out for profit maximization purposes and good success Idowu (2014). The inclusion of financial, surroundings of corporation's operationalization, people's wellbeing, and welfare which would be integral aspect of firms' activities, modality, morality, conscientious efforts, consensus, which can be monitored and evaluated by company's management and auditors is called Corporate Social Responsibility (CSR) Carroll (2016), Mogaka (2016).

CSR generally deals with social matters. For example, the area of CSR would classically be refining access to schooling and learning amongst indigenes and public, giving them better health care chances and refining their ecological environments Freeman and Dmytriyev (2017).

In light of the above, this study therefore seeks to investigate effect of CSR on investment efficiency (IE) of quoted oil and gas firms in Nigeria in order to ascertain whether CSR has positive or negative effect on CSR performing firms.

\subsection{STATEMENT OF THE PROBLEM}

A lot of studies have been carried out on effect of CSR on financial performance, but very few have been done on effect of CSR and/or investment efficiency. Past works studied the effect of CSR on investment efficiency in developed countries Benlemlih and Bitar (2015) \& Cook, et al, 2018, but very few studies have been conducted in developing countries especially in Nigeria. Several researchers claim that great CSR participation is connected with high corporation's performance and greater corporation value Benlemlih and Bitar (2015). CSR undertakings could also cause clashes of interest amongst interested parties (Krüger, 2015).

The main discrepancy between this study and the above past studies is that this study examines effect of CSR on investment efficiency of quoted oil and gas in Nigeria since less work has been specifically done on this very sector peculiarly in Nigeria. The study is based on the technique of quantitative analysis of effect of CSR using the audited annual reports and accounts of oil and gas firms quoted on the floor of Nigerian Stock Exchange (NSE) as at 31 ${ }^{\text {st }}$ December, 2019.

\subsection{RESEARCH HYPOTHESES}

The null hypotheses formulated for this study are as below:

$\mathrm{Ho}_{1}$ : CSR Charitable Donation Expenditure does not significantly affect the investment efficiency of oil and gas firms in Nigeria.

$\mathrm{Ho}_{2}$ : There is no significant relationship between CSR Expenditure on Education and investment efficiency of oil and gas firms in Nigeria.

$\mathrm{Ho}_{3}$ : There is no significant relationship between CSR Societal Expenditure and investment efficiency of oil and gas firms in Nigeria

$\mathrm{Ho}_{4}$ : CSR Health Expenditure does not significantly affect investment efficiency of oil and gas firms in Nigeria.

Ho5: CSR Environmental Expenditure does not have significant effect on investment efficiency of oil and gas firms in Nigeria.

$\mathrm{Ho}_{6}$ : There is no significant relationship between CSR Sports Expenditure and investment efficiency of oil and gas firms in Nigeria. 


\subsection{SCOPE OF THE STUDY}

The study is delimited to seven (7) oil and gas firms quoted on the floor of NSE as at December 31st, 2019 due to availability of disaggregated CSR data. The study covered a period of ten (10) years (2010-2019). Whereas year 2010 was chosen as a significant year because that is the year that "Nigerian Oil and Gas Industry Content Development (NOGICD)" was established, year 2019 made it a decade (10 years) to ensure reasonable and reliable results since all the annual reports are available on these dates.

\section{LITERATURE REVIEW AND THEORETICAL FRAMEWORK 2.1. CONCEPT OF CSR}

According to Mallouh and Tahtamouni (2018), when a company is no longer operationally myopic on its charitable obligations to such vicinity where it operationalizes and esteems the wellbeing of its immediate surroundings where itself is the citizen and plays a role of a responsible citizenry, it becomes a step further to boost their financial wellbeing. CSR can be looked at as a deliberate action to both internal and external stakeholders which go beyond the purview of Law (Amodu, 2017). Carroll (2016) stated that in general, CSR specifically might have showcased its comprehension to mean strategies with implementation that businesses introduced to ensure that people, corporation investors, other than business owners, are protected and considered in the way they strategized and operationalize.

\subsection{FORMS OF CSR IN OIL AND GAS FIRMS IN NIGERIA}

1) Corporate Social Responsibility Charitable Donation Expenditure (CSRCDE): Such humanitarian gestures could be in sort of financial (currency assistances) or non-financial like food stuff, apparel, houses, relief materials, services, clothing, toys, food, vehicle, donation of blood and transplant Madugba and Okafor (2016), Ohaka and Ogaluzor (2018).

2) Corporate Social Responsibility Expenditure on Education (CSREDE): These expenses for examples are studentship awards, young people's improvement exercise and the provision of learning amenities, donation of houses and equipment to improve the coaching with educational setting, purchase of stationeries, donation of school bus, building of classroom blocks, computers to schools, award of scholarships to indigent pupils and students from poor homes and intelligent children as an encouragement, building and donating staff quarters to teachers Ezeji and Okonkwo (2016), Madugba and Okafor (2016), Tijani et al. (2017).

3) Corporate Social Responsibility Societal Expenditure (CSRSE): This among others includes rewards remunerated to workers as expenses incurred towards the public, gifts to public and community (people), rural development, investing in females through giving occupational teaching, occupation and health care spending, security with work of the needy, aids, public benefit provision, social privileges, consumer safety, bodily wellbeing, giving a proportion of profits to community developments Mandal and Banerjee (2015), Mentor (2016), Cho et al. (2019).

4) Corporate Social Responsibility Health Expenditure (CSRHE): This is firm's spending on the aspect of health on both their employees and for 
community (stakeholders), health need of the needy within the society; reducing the conveyance contamination and pollutions in the surroundings where the firm operates Iqbal et al. (2013).

5) Corporate Social Responsibility Environmental Expenditure (CSREE): These are costs expended for preservation of the surroundings where operations take place. The expenses are on environmental investment, pollution performance, preservation of natural resources, discarding of manufacturing wastes by using safe means, prevention of noise and air pollution etc. (Jarbou, 2007 as cited in Mallouh and Tahtamouni (2018), Cho et al. (2019).

6) Corporate Social Responsibility Sports Expenditure (CSRSPE): Agreeing with Jajić and Jajić (2021), 'aligning the view that, there is existence of a thing other than profit, "the business unceasingly support mutual schemes and gifted persons in the educational arenas, sports, science, technical know-how, well-being, culture and arts'. In addition, to give immense consideration to the mutual popular sports, such as football and basketball, momentous backing is directed towards encouraging development of sports associations related to sports which the government often times gives little or entirely no attention to, like judo, wrestling, karate, biking, skiing, gymnastics and other forms of sports that can bring people like physically challenged youths together Jajić and Jajić (2021).

\subsection{CONCEPTS AND MEASUREMENT OF INVESTMENT EFFICIENCY (IE)}

IE of a company is its capacity to invest in all positive net present value (NPV) projects Anwar and Malik (2020). IE means those ventures with positive NPV where market frictions like unfriendly choice or agency costs are not present Ibrahim and Ibrahim (2021).

\subsection{THEORETICAL FRAMEWORK}

\section{Social Contract Theory}

According to Omran and Ramdhony (2015), the historical precedence of this theory started in Hobbes (1946), Rousseau (1968) and Locke (1986). Donaldson (1982) sights the corporation and societal association in the theoretical point of view. His opinion is that there is an unspoken social agreement that exists among corporation with the people and community. License to operate with regards to this theory originates from standpoint that all firms require implicit and explicit authorization from regimes, societies in relation to other interested parties to participate in Mwangangi (2018).

\section{Stakeholders Theory}

The leading scholars of stakeholder theory among others are: Freeman (1984), Savage et al. (1991), Graves et al. (2001), O'Dwyer (2003), Boatright (2003), Wicks et al. (2004), Wearing (2005), Deegan (2013) etc. as cited in Omran \& Ramdhony (2015). Stakeholder theory proposes that a firm's aim is creation of stakeholder's value to the best of its ability. Since Stakeholder theoreticians' opinion that the company is a crew of interested parties within and outside (e.g., shareholders, employees, customers, suppliers, creditors, and neighbouring communities)-

"Stakeholders," which was at first referred to as individuals that are influenced by 
and/or could affect the accomplishment of the firm's goals (Freeman, 1984), stakeholder theory is the underpinning theory for this research work.

\subsection{EMPIRICAL REVIEW}

Yazdani and Barzegar (2017) investigated 'Relationship between CSR and investment performance of firms listed in Tehran Stock Exchange (TSE)'. The work examined the association amidst CSR and investment performance of companies quoted in the TSE. Peculiar and temporary domains are the companies quoted in TSE from 2010-2013, correspondingly. Score for disclosure of CSR and the IE were measured as independent and dependent variables, respectively. The study analyzed the content for determining the level of CSR, a discloser checklist, social responsibility model of Barzegar (2013) and a binary technique are employed. The study is an applied and correlative based on objective, nature and technique. 93 firms were sampled with the aid of systematic elimination. Study outcomes reveal a significant association between CSR and investment performance of firms quoted in TSE.

Ho et al. (2021) studied on 'How does corporate social performance affect investment inefficiency? The study examines the association amid corporate social performance (CSP) and IE in the Chinese stock market. By means of the distinctive CSP ratings scores from the Rankins CSP Ratings (RKS), the study discover that socially responsible firms are more proficient in their investment. The study also discovers that the impact of CSP in decreasing investment inefficiency is more obvious in overinvestment situations. Also, the study suggests strong and robust proof that CSP significantly increases IE in state-owned enterprises.

Kirsten et al. (2018) study dual vital means by which corporate social responsibility (CSR) influences company worth which are IE and innovation. They establish that companies with greater CSR implementation spend more proficiently: such companies are not disposed to spend in unfavourable NPV ventures (overinvestment) and less prone to sacrifice positive NPV ventures (underinvestment). They as well discover that companies with greater CSR execution produce more rights with patent credentials. Mediation exploration shows that companies with greater CSR execution are highly lucrative and appreciated, consequences partly attributable to proficient reserves and innovation. These outcomes, robust to replacement model stipulations, provide backing to rational hind stakeholder theory.

Lee (2020) carried out an investigation on 'CSR and Investment Efficiency: Evidence from an Emerging Asian Market. The study aims to examine conflicting opinions of the association between CSR and IE in the main Asian emerging stock (AES) market. Experiential outcomes reveal that CSR significantly alleviates investment inefficiency (II) amongst Taiwanese companies. The finding corroborates the view that socially responsible Taiwanese companies have less agency difficulties and lesser information asymmetry, hence decreasing II. The empirical outcomes as well review that CSR has a more obvious impact in alleviating II for Taiwanese companies with more effective corporate governance. Peculiarly, because of compulsory preparation of CSR reporting, CSR is connected with lesser IE for Taiwanese companies with fragile governance machineries within 20142017. The discoveries of the study depict suggestions for government establishments, company executives, and shareholders in terms of CSR policy creation, execution of CSR plans, and running of investment portfolios.

Benlemlih and Bitar (2015) researched on 'CSR and Investment Efficiency'. The sample size of 21,030 US firm-year interpretations that represent above 3,000 
different companies above years 1998-2012. In uniformity with the study prospects that great CSR companies benefit little information asymmetry with great stakeholders' solidarity, the study discovered significant with robust indication that great CSR participation reduces investment inefficiency which as result enhances investment efficiency. Also, the study findings recommend that CSR components that have direct link with firms' major undertakings are pertinent in decreasing investment inefficiency as paralleled to those related to secondary stakeholders (e.g., human rights and community involvement). Finally, other outcomes indicated that the effect of CSR on IE is more pronounced during the subprime crisis. Mutually, the outcomes highlighted the vital role which CSR plays in modeling company's investment conduct and efficiency. This is also supported by Benlemlih and Bitar (2018) whose study indicated that high CSR disclosures decrease investment inefficiency and increase investment efficiency.

Zhong and Gao (2017) carried out research and established that CSR disclosures influenced investment efficiency, which can cause reduction of the difficulty of information asymmetry. CSR disclosures motivate and cause companies to finance the environment. A firm is gratified to participate in environmental protection activities to meet its stakeholders' demands. It indicates that CSR disclosures assists in reduction of information asymmetry and refining investment efficiency. The impact of governance on IE is more with CSR disclosures.

Samet and Jarboui (2017) conducted a study on the topic, 'How does CSR contribute to investment efficiency?' The study investigated the direct and indirect association amongst CSR performance with IE. Panel dataset consisting of 398 quoted firms in Europe in the European STOXX 600 from 2009 to 2014. Initial outcome reveals that companies which have more CSR performance venture proficiently. Analysis differentiating two diverse circumstances were conducted: underinvestment and overinvestment. Concentrating on under-investing firms, the study highlight that CSR performance improves their investment levels by moderating information asymmetry. However, for over-investing corporations, CSR performance decreases investment excess by alleviating free cash flow issues. Generally, the findings recommend a part for CSR indirectly bettering firm-level IE by assisting corporations address agency hitches and information asymmetry issues. The link among CSR performance with IE which is positive reveals CSR execution as a means to put smile on stakeholders' faces. The firms' CSR undertakings can lead to competitive benefit for the firm especially when caring for environs with the firms' problem of information asymmetry.

Erawati et al. (2020) carried out a study on "The Role of CSR in the Investment Efficiency: Is It Important? The study was on how CSR disclosures aid; mediate between impact family ownership and corporate governance (CG) on investment efficiency. STATA was employed to interpret available data sourced. Sample size was 210 industrial firms quoted on the Indonesian Stock Exchange, which were in the family businesses category from 2016 to 2018. The initial discovery reveals that CSR regulates the impact of family ownership on investment efficiency. The other finding reveals that CSR disclosures can mediate the impact of CG on investment efficiency. CSR undertakings play a key role when making choice, and via CSR disclosures, CG takes a higher impact on investment efficiency.

\subsection{GAPS IN THE LITERATURE}

A lot of studies conducted on relationship between CSR and IE is conducted in developed countries. Not much have been conducted in developing countries like Nigeria. The majority of the past studies employed aggregated method of CSR 
instead of disaggregated method. Also, very few studies have been conducted using oil and gas sector, which has necessitated this study in order to make contributions to knowledge.

Independent Variables

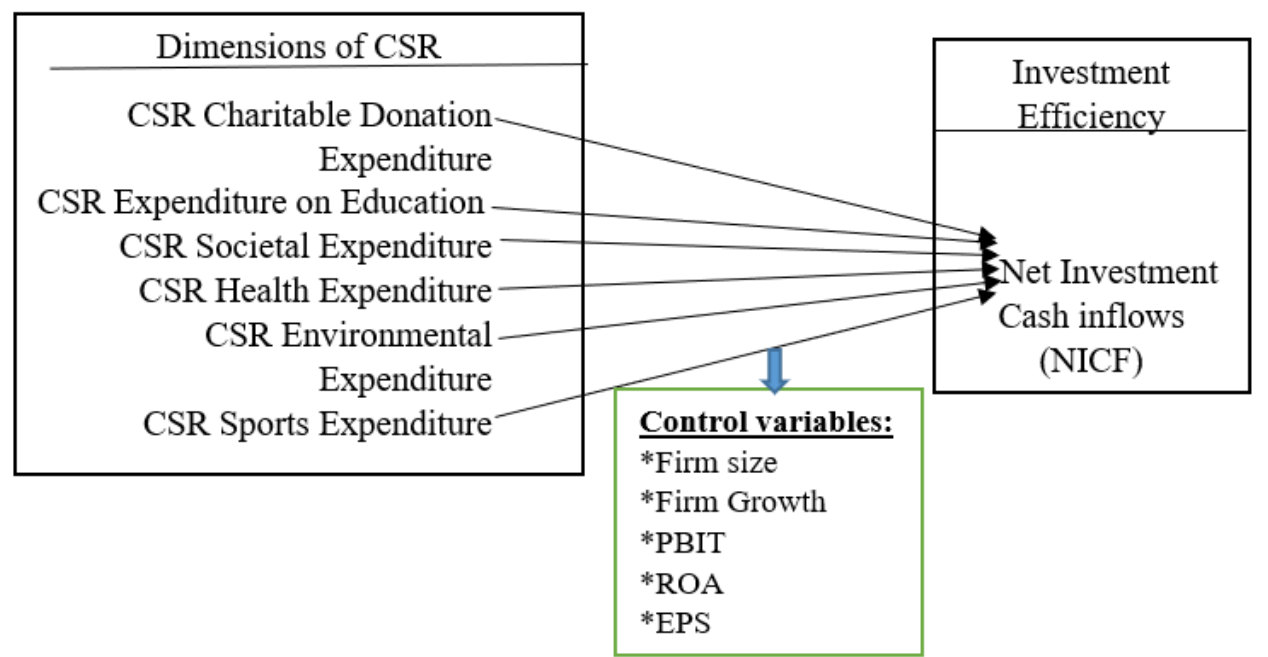

Figure 1 Model of the Study

Source: Modified Model from the works of Al Qaisi (2019), Ibrahim and Ibrahim (2021)

\section{RESEARCH DESIGN}

The study adopted ex-post facto research design because the secondary data already existed. The information relating to IE on financial statement of oil and gas firms is under their cash flow statements. Owing to this, the net investment cash flows which represent the NPV of projects and investments are used to measure the IE of the quoted oil and gas firms in Nigeria.

\subsection{POPULATION OF THE STUDY AND SAMPLING DESIGN}

The population of this study constitutes of the twelve (12) quoted oil and gas firms on the Nigeria Stock Exchange as at $31^{\text {st }}$ December, 2019. The sample size of seven (7) was chosen from oil and gas firms which CSR reportings are in disaggregated form. Also, some listed oil and gas firms did not quantify (in figures) their CSR report in the audited annual reports and accounts if at all they are practicing CSR which led to selection of seven (7) oil and gas firms (Eterna, Forte Oil, 11 plc (Mobil), Mrs Oil, Oando, Seplat and Total Nig. Plc.) which data are available on disaggregated basis.

\subsection{METHODS OF DATA COLLECTION}

The study used secondary data that were collected from the annual reports and accounts of the sampled quoted oil and gas firms listed on the NSE as at December $31^{\text {st }}$, 2019. The study is delimited to seven (7) oil and gas firms quoted on the floor of NSE as at December 31st, 2019 due to availability of disaggregated CSR data. The study covered a period of ten (10) years (2010-2019). Whereas year 2010 was chosen as a significant year because that is the year that "Nigerian Oil and Gas Industry Content Development (NOGICD)" was established, year 2019 made it a 
decade (10 years) to ensure reasonable and reliable results since all the annual reports are available on these years.

\subsection{TECHNIQUES OF DATA ANALYSIS}

The statistical methods used are descriptive statistics, multiple regression and variance inflation factor (VIF) to test for multicollinearity. The analysis was conducted with the aid of SPSS Version 23 Software package.

\subsection{MODEL SPECIFICATION AND VARIABLE MEASUREMENT}

\subsubsection{MODEL SPECIFICATION}

$\mathrm{NICF}=\mathrm{f}$ (CSRCDE, CSREDE, CSRSE, CSRHE, CSREE, CSRSPE, FZ, FG, PBIT, ROA, EPS) .... (1)

$\mathrm{NICF}=\beta_{0}+\beta_{1} \mathrm{CSRCDE}_{\mathrm{it}}+\beta_{2} \mathrm{CSREDE}_{\mathrm{it}}+\beta_{3} \mathrm{CSRSE}_{\mathrm{it}}+\beta_{4} \mathrm{CSRHE}_{\mathrm{it}}+\beta_{5} \mathrm{CSREE}_{\mathrm{it}}+\beta_{6} \mathrm{CSRSPE}_{\mathrm{i}}$ ${ }_{\mathrm{t}}+\beta_{7} \mathrm{FZ}_{\mathrm{it}}+\beta_{8} \mathrm{FG}_{\mathrm{it}}+\beta_{9} \mathrm{PBIT}_{\mathrm{it}}+\beta_{10} \mathrm{ROA}_{\mathrm{it}}+\beta_{11} \mathrm{EPS}_{\mathrm{it}}+\mathrm{et}_{\mathrm{it}}$

.... (2)

\section{Where:}

$\mathrm{NICF}=$ Net Investment Cash in flows

CSR=Corporate Social Responsibility,

CSRCDE $=$ CSR Charitable Donation Expenditure

CSREDE $=$ CSR Education Expenditure,

CSRSE $=$ CSR Societal Expenditure

CSRHE $=$ CSR Health Expenditure ,

CSREE $=$ CSR Environmental Expenditure

CSRSPE $=$ CSR Sports Expenditure,

FZ= Firm Size,

$\mathrm{FG}=$ Firm Growth,

PBIT= Profit before Interest and Tax

ROA= Return on Assets

EPS= Earnings per Share

$\mathrm{e}=$ Error term (representing the combined effect of omitted variables),

$f=$ functional relationship

$\beta=$ Coefficient of the independent variables,

$\alpha=$ a constant,

it $=$ Dated panel data

\section{DISCUSSION OF FINDINGS}

\subsection{REGRESSION RESULTS}

Since regression analysis consolidates the restrictions of the correlation matrix in data analysis as the result of the latter's weakness of ability to reveal the track of link amongst surrogates, but cannot show the strength of the link, regression analysis is therefore employed for this study's analysis Kajola et al. (2017), Kajola et al. (2018). 
Table 1 Multiple Regression Results

\begin{tabular}{|c|c|c|c|c|c|}
\hline & $\begin{array}{l}\text { Unstandardized } \\
\text { Coefficients }\end{array}$ & & $\begin{array}{c}\text { Standardized } \\
\text { Coefficients }\end{array}$ & $\begin{array}{c}\text { T- } \\
\text { value }\end{array}$ & Sig. \\
\hline Model & B & $\begin{array}{l}\text { Std. } \\
\text { Error }\end{array}$ & Beta & & \\
\hline (Constant) & -1.075 & 2.044 & & -0.526 & 0.601 \\
\hline CSRCDE & -0.102 & 0.049 & -0.283 & -2.082 & 0.042 \\
\hline CSREDE & 0.48 & 0.186 & 0.315 & 2.582 & 0.012 \\
\hline CSRSE & 0.615 & 0.225 & 0.386 & 2.727 & 0.008 \\
\hline CSRHE & -0.027 & 0.038 & -0.084 & -0.715 & 0.478 \\
\hline CSREE & -0.011 & 0.031 & -0.037 & -0.336 & 0.738 \\
\hline CSRSPE & -0.086 & 0.038 & -0.259 & -2.226 & 0.03 \\
\hline $\mathrm{FZ}$ & -0.043 & 0.086 & -0.05 & -0.492 & 0.625 \\
\hline $\mathrm{FG}$ & -0.369 & 1.265 & -0.033 & -0.292 & 0.772 \\
\hline PBIT & 0.246 & 0.196 & 0.181 & 1.25 & 0.216 \\
\hline ROA & 0.043 & 0.04 & 0.129 & 1.088 & 0.281 \\
\hline EPS & 0.012 & 0.037 & 0.038 & 0.313 & 0.755 \\
\hline
\end{tabular}

a. Dependent Variable: NICF

Source: Output from SPSS Version 23.

The table above shows the result of multiple linear regression. The table reveals that both CSRCDE and CSRSPE have significant negative impact on net investment cash inflows of listed DMBs in Nigeria at $5 \%$ because their P-values $(0.042 ; 0.030)$ are less than p-value of 0.05 with negative coefficient values (B) of -.102 and -.086. CSREDE and CSRSE depict significant positive impact on net investment cash inflows of listed DMBs in Nigeria with the P-values, 0.012 and 0.008 respectively with the corresponding positive coefficients (B) values $(.480 ; .615)$. However, CSRHE and CSREE depict insignificant negative impact on net investment cash inflows of listed DMBs in Nigeria with the p-values 0.478 and 0.738 which are more than 5\% (0.05) level of significance. Evidently, their corresponding coefficient (B) values are negative $(-.027 ; \&-0.011)$ as depicted in the table above.

\begin{tabular}{|c|c|c|c|c|}
\hline Hypothesis & Coef. & $\begin{array}{c}\text { T- } \\
\text { value }\end{array}$ & $\begin{array}{l}\text { P- } \\
\text { value }\end{array}$ & Decision \\
\hline $\begin{array}{l}\text { Ho1: CSRCDE does not significantly affect the investment } \\
\text { efficiency of oil and gas firms in Nigeria }\end{array}$ & $-\overline{102}$ & -2.082 & 0.042 & Reject \\
\hline $\begin{array}{l}\text { Ho2: There is no significant relationship between CSREDE } \\
\text { and investment efficiency of oil and gas firms in Nigeria }\end{array}$ & 0.480 & 2.582 & 0.012 & Reject \\
\hline $\begin{array}{l}\text { Ho3: There is no significant relationship between CSRSE } \\
\text { and investment efficiency of oil and gas firms in Nigeria }\end{array}$ & 0.615 & 2.727 & 0.008 & Reject \\
\hline $\begin{array}{l}\text { Ho4: CSRHE does not significantly affect investment } \\
\text { efficiency of oil and gas firms in Nigeria }\end{array}$ & 0.027 & -.715 & 0.478 & Accept \\
\hline $\begin{array}{l}\text { Ho5: CSREE does not have significant effect on investment } \\
\text { efficiency of oil and gas firms in Nigeria }\end{array}$ & 0.011 & -.336 & 0.738 & Accept \\
\hline $\begin{array}{l}\text { Ho6: There is no significant relationship between CSRSPE } \\
\text { and investment efficiency of oil and gas firms in Nigeria }\end{array}$ & 0.086 & -2.226 & 0.030 & Reject \\
\hline
\end{tabular}

Source: Output from SPSS Version 23 
The results from the table above 4.5.1 prove that four (4) out of the six (6) null hypotheses formulated for this study are rejected, while two (2) are accepted. It therefore means that four (4) independent variables revealed significant effect on IE of oil and gas firms in Nigeria while two (2) depict insignificant effect. The rule of thumb for the test above is that where p-value is below $5 \%(0.05)$ the null hypothesis should be rejected. And if the p-value is exceeding $5 \%(0.05)$ the null hypothesis should be accepted Al Qaisi (2019) as in the cases of null hypotheses numbers four and five $\left(\mathrm{Ho}_{4} ; \mathrm{Ho}_{5}\right)$ above (CSRHE; CSREE) with p-values of 0.478 and 0.738 respectively.

\subsection{MODEL SUMMARY}

\begin{tabular}{|c|cccc|}
\hline \multicolumn{5}{|c}{ Table $\mathbf{3}$ Model Summary } \\
\hline Model & $\mathbf{R}^{\mathbf{2}}$ & Adj. R & Prob. $>$ F & Durbin-Watson \\
\hline 1 & .438 & .331 & 0.000 & 1.627 \\
\hline
\end{tabular}

The model summary above reveals the Sig. F change (Prob. > F) of 0.000 which value is below $5 \%(0.05)$ level of significance. This implies that the whole model for this study is fit for analysis. From the table above, the coefficient of determination $\left(R^{2}\right)$ reveals the extent to which the independent variables explain the dependent variable. It is therefore evidenced that the degree to which variations in dependent variable (NICF) can be explained by independent variables is $43.80 \%$. The DurbinWatson's result of 1.627 which is less than 2 portends that the regression model has a good fit.

\subsection{SUMMARY OF FINDINGS}

From the results of the findings above, it is discovered that: The results of the significant variables corroborate Benlemlih and Bitar (2015) whose study outcomes highlight the vital role which CSR plays in modeling company's investment performance with efficiency, and Yazdani and Barzegar (2017) whose study outcomes reveal a significant association between CSR and investment performance of firms quoted in TSE. The results are also in tandem with Erawati et al. (2020) who conducted a study on 'The Role of CSR in the Investment Efficiency: Is It Important? Their results reveal that CSR is indeed important. The results of the significant variables corroborate Zhong and Gao (2017) who carried out research and found that CSR disclosures affect IE significantly.

This study substantiates the study of Kirsten et al. (2018) who discover that companies with greater CSR execution produce more rights with patent rights. Intermediation exploration shows that companies with greater CSR execution are highly lucrative and appreciated, consequences partly attributable to proficient reserves and innovation that companies with greater CSR execution produce more rights with patent credentials.

This study upholds Samet and Jarboui (2017) whose study reveals positive link with CSR performance and IE,that executing a CSR approach is a potent means to inspire firm progress and safeguard stakeholders' benefits. The firm's CSR undertakings could lead to rivalry benefit for the firm especially when caring for environs with the firms' problem of information asymmetry. This study is also consistent with Lee (2020) whose study's empirical outcomes reveal that CSR significantly alleviates amongst Taiwanese companies. 


\subsection{CONCLUSION AND RECOMMENDATIONS}

This study investigated effect of CSR on IE of quoted oil and gas firms in Nigeria. The proxy for IE used by study from audited annual reports of the firms is net investment cash inflows (NICF) while the independent variables are made up of six (6) as proxies used for CSR as found in the annual reports and accounts of the oil and gas firms. Having analysed the results of the findings and test of the formulated null hypotheses, the study therefore makes the following recommendations:

1) The oil and gas firms should improve their expenditure on CSR Charitable donation expenditure (CSRCDE) and monitor it meticulously against window dressing services.

2) The executive of these firms should be consistent in CSR Expenditure on Education (CSREDE) since it reveals a positively significant effect on their investment efficiency.

3) These firms ought to put up with CSR Societal Expenditure (CSRSE) as it indicates positively significant effect on their investment efficiency.

4) CSR Health Expenditures (CSRHE) on citizenry, community and the environment have to be prioritized irrespective of the degree of association with investment presently.

5) CSR Environmental Expenditure (CSREE) ought to be stimulated since it is a short-term investment with a long-term benefit.

6) The firms have to be consistent in CSR Sport Expenditure (CSRSPE) so as to benefit at long run even though it may seem unprofitable now.

\subsection{SUGGESTIONS FOR FURTHER RESEARCH}

This study investigates effect of CSR on IE of oil and gas firm quoted on the floor of NSE as at 31 st December, 2019 in Nigeria. As stated by Erawati et al. (2020), the challenge of IE is a composite challenge that is yet to be broadly investigated, so there exist several prospects for future studies. For generalization purposes of the study's key findings, prospective study should cover the framework of effect of CSR on IE by bringing into consideration other countries. The study also makes provision for prospective researchers to study other factors which could influence investment efficiency. Prospective research should as well investigate other sectors apart from oil and gas, like mining, quarry, construction etc

\section{REFERENCES}

Al Qaisi, F. (2019). Corporate social responsibility effect on firm's financial performance in Jordan, Int. J. Monetary Economics and Finance, 12 (4), pp.325-342. Retrieved from https://doi.org/10.1504/IJMEF.2019.101942

Anwar, R, \& Malik, J.A. (2020). When does corporate social responsibility disclosure affect investment efficiency? A new answer to an old question. 10.1177/2158244020931121 journals.sagepub.com/home/sgo. Retrieved from https://doi.org/10.1177/2158244020931121

Benlemlih, M., \& Bitar, M. (2015). Corporate social responsibility and investment efficiency. Academy of Management Proceedings,2015(1). Retrieved from https://doi.org/10.5465/ambpp.2015.12768abstract

Benlemlih, M., \& Bitar, M. (2018). Corporate social responsibility and investment efficiency. Journal of Business Ethics, 148(3), 647-671. Retrieved from https://doi.org/10.1007/s10551-016-3020-2 
Carroll, A. B. (2016). Carroll's pyramid of CSR: taking another look. International Journal of Corporate Social Responsibility, 1(1). Retrieved from https://doi.org/10.1186/s40991-016-0004-6

Chih, H. H., Miao, W. C., \& Chuang, Y. C. (2014). Is corporate social responsibility a double-edged sword? Evidence from fortune glob.

Cho, S. J., Chung, C. Y., \& Young, J. (2019). Study on the relationship between CSR and financial performance. Sustainability (Switzerland), 11(2). Retrieved from https://doi.org/10.3390/su11020343

Cook, K. A., Romi, A. M., Sánchez, D., \& Sánchez, J. M. (2019). The influence of corporate social responsibility on investment efficiency and innovation. Journal of Business Finance \& Accounting, 46(3-4), 494-537. Retrieved from https://doi.org/10.1111/jbfa.12360

Elberry, Noha, and Khaled Hussainey. (2020). Does corporate investment efficiency affect corporate disclosure practices? Journal of Applied Accounting Research 21: 309-27. Retrieved from https://doi.org/10.1108/JAAR-032019-0045

Erawati, N.M.A, Sutrisno, T, Hariadi, B, \& Saraswati, E. (2020). The role of corporate social responsibility in the investment efficiency: Is It Important? Journal of Asian Finance, Economics and Business, 8 (1), 169-178. Online ISSN 22884645 doi: 10.13106. Retrieved from https://www.koreascience.or.kr/article/JAK0202100569391284.page

Ezeji, C.E. and Okonkwo, O.N. (2016). Corporate social responsibility: a study of oil transnational corporations in Nigeria. International Journal of Business \& Law Research 4(2):1-9. Retrieved from http://seahipaj.org/journalsci/june-2015/june-2016/IJBLR/full/IJBLR-J-1-2016.pdf

Fernando, S., \& Lawrence, S. (2014). A theoretical framework for CSR practices: Integrating legitimacy theory, stakeholder theory and institutional theory. Journal of Theoretical Accounting, 10(1). Retrieved from https://www.researchgate.net/profile/Susith-

Fernando/publication/290485216_A_theoretical_framework_for_CSR_prac tices_Integrating_legitimacy_theory_stakeholder_theory_and_institutional_t heory/links/5a8629ee458515b8af890861/A-theoretical-framework-forCSR-practices-Integrating-legitimacy-theory-stakeholder-theory-andinstitutional-theory.pdf

Freeman, R. E., \& Dmytriyev, S. (2017). Corporate social responsibility and stakeholder theory: Learning from each other. Symphonya. Emerging Issues in Management, 2(1),7-15. Retrieved from https://doi.org/10.4468/2017.1.02freeman.dmytriyev.

Ho, K-C., Li, H-M., \& Gong, Y. (2021). How does corporate social performance affect investment inefficiency? An empirical study of China market. http://www.elsevier.com/journals/borsa-istanbul-review/2214-8450. Retrieved from https://doi.org/10.1016/j.bir.2021.06.016

Ibrahim, A, \& Ibrahim, A. (2021). The impact of risk disclosure on investment efficiency. Alexandria Journal of Accounting Research (5) 1.

Idowu, A. (2014). CSR in Nigerian banking industry : when will the lip-service games end? 5(22). Retrieved from https://citeseerx.ist.psu.edu/viewdoc/download?doi=10.1.1.999.7615\&re $\mathrm{p}=\mathrm{rep} 1 \&$ type $=\mathrm{pdf}$

Iqbal, N., Ahmad, N., \& Kanwal, M. (2013). Impact of CSR on profitability of Islamic and conventional financial institutions. Applied mathematics in engineering, 

management
and
technology
$1(2)$.
https://www.researchgate.net/profile/Naveed-Ahmad-
9/publication/259560031_Impact_of_Corporate_Social_Responsibility_on_
Profitability_of_Islamic_and_Conventional_Financial_Institutions/links/586 6f8f008aebf17d39aeca1/Impact-of-Corporate-Social-Responsibility-on-
Profitability-of-Islamic-and-Conventional-Financial-Institutions.pdf

Ishola, J.A. \& Ishola, O. P. (2019). Corporate social responsibilty: its effects on the performance of insurance sector in Nigeria. Ilorin journal of human resource management (ijhrm). 3(2), 21-33.

Jajić, B., \& Jajić, J. (n.d) (2021). CSR and sport. University of educons, Serbia.JEL classification: L83, M14.

Kajola, S. O., Anene, E. C., \& Desu, A. A. (2017). Corporate social responsibility and financial performance of the Nigerian listed firms. 2(1), 71-82. Retrieved from https://www.futa.edu.ng/journal/papers/paper_6_1530187570.pdf

Kajola, S.O. Adedeji, S. B. Olabisi, J., \& Babatolu, A.T. (2018), Effect of credit risk management on financial performance of Nigerian listed deposit money banks. Policy \& governance ISSN 2394-3351. 5 (6).. Retrieved from https://doi.org/10.19085/journal.sijbpg050601

Lee, M. (2020). Corporate social responsibility and investment efficiency: Evidence from an Emerging Asian Market.p. De La Salle University Research Article. Pp.1-16.

Ma, L., Ma, S., \& Tian, G. (2017). Corporate opacity and cost of debt for family firms. European Accounting Review, 26(1), 27-59. Retrieved from https://doi.org/10.1080/09638180.2015.1087868.

Madugba, J.U. \& Okafor, M.C. (2016). Impact of corporate social responsibility on financial performance: Evidence from listed banks in Nigeria. Expert journal of finance. (4)(1), 1-9. Retrieved from https://finance.expertjournals.com/23597712-401/

Mallouh, A. A., \& Tahtamouni, A. (2018). The impact of social responsibility disclosure on the liquidity of the Jordanian industrial corporations The impact of social responsibility disclosure on the liquidity of the Jordanian industrial corporations Alaa Abu Mallouh Asem Tahtamouni *. December. Retrieved from https://doi.org/10.1504/IJMFA.2018.093504

Mandal, K., \& Banerjee, S. (2015). Is 'Societal expenditure' an alternative route to business success? an empirical study. Journal of Advanced Management Science, 3(1). Retrieved from https://doi.org/10.12720/joams.3.1.31-37

Mann, S. V., \& Sicherman, N. W. (1991). The agency costs of free cash flow: Acquisition activity and equity issues. Journal of Business, 64, 213-227. Retrieved from https://doi.org/10.1086/296534

McLean, R. D., Zhang, T., \& Zhao, M. (2012). Why does the law matter? Investor protection and its effects on investment, finance, and growth. Journal of Finance. Retrieved from https://doi.org/10.1111/j.15406261.2011.01713.x

Mentor, M. (2016). "The effects of corporate social responsibility on financial performance". $\quad$ Retrieved

https://stars.library.ucf.edu/honorstheses/47.

Mogaka, M.M.(2016). Effect of corporate social responsibilty on financial performance of in telecommunication industry in Kenya, M.Sc.dissertation, University of Nairobi. 
Mohammadi, S. M. (2014). The relationship between financial reporting quality and investment efficiency in Tehran stock exchange. International Journal of Academic Research in Business and Social Sciences, 4, 104-113. Retrieved from https://doi.org/10.6007/IJARBSS/v4-i6/930

Mwangangi, S. A.(2018) Effect of corporate social responsibility on performance of manufacturing firms in Kenya. Unpublished Ph.D thesis. Jomo Kenyatta University of Agriculture and Technology.

Ohaka, J., \& Ogaluzor, O. I. (2018). CSR accounting and the effect of corporate social responsibility accounting and the effect of donations on profitability of oil and gas companies in Nigeria. November. Retrieved from https://doi.org/10.6007/IJARAFMS/v8-i3/4835

Omran, M.A., \& Ramdhony, D. (2015). Theoretical perspectives on corporate social responsibility disclosure: A critical review. 5 (2). https://www.researchgate.net/publication/280155907.

Samet, M., \& Jarboui, A. (2017). How does corporate social responsibility contribute to investment efficiency? Journal of multinational financial management, 40, 33-46. Retrieved from https://doi.org/10.1016/j.mulfin.2017.05.007

Tijani, A.A., Adeoye, A. 0., \& Alaka, N. S. (2017). Effects of corporate social responsibility on banks financial performance in Nigeria : A Study of United Bank of Africa. December 2018. Retrieved from https://www.researchgate.net/profile/Abayomi-

Adeoye/publication/322205356_Effects_of_Corporate_Social_Responsibilit y_on_Banks_Financial_Performance_in_Nigeria_A_Study_of_United_Bank_of _Africa/links/5c21be0ea6fdccfc70670e98/Effects-of-Corporate-SocialResponsibility-on-Banks-Financial-Performance-in-Nigeria-A-Study-ofUnited-Bank-of-Africa.pdf

Ugwukah, A, C., \& Ohaja, O. I., (2016). Historigraphic assessment of the petroleum industry and its impact on the Nigerian economy. Historical www.iiste.org ISSN 2224-3178 (Paper) ISSN 2225-0964 (Online), Vol. 36. Retrieved from https://publication.babcock.edu.ng/asset/docs/publications/HIST/9672/ 3145.pdf

Vassiliou, M.S. (2018). Historical dictionary of the petroleum industry.ISBN: 9781538111598. TN865.V382018.

Yazdani, R., \& Barzegar, G.(2017). The relationship between corporate social responsibility and investment performance of companies listed in Tehran Stock Exchange. Science Arena Publications Specialty Journal of Accounting and Economics Available online at www.sciarena.com,3(1):67-72. Retrieved from

https://sciarena.com/storage/models/article/d3d5FQvj5qQqlgPvA0Zmjtx JPXCn7SBwEc7GKHibTiz4xy4sk0erpv78dfoJ/the-relationship-between-

corporate-social-responsibility-and-investment-performance-ofcompanies-l.pdf

Zhong, M. (2017). Does corporate social responsibility disclosure improve firm investment efficiency? Evidence from China. Review of Accounting and Finance, 16(3), 348-365. Retrieved from https://doi.org/10.1108/RAF-062016-0095

Zhong, M., \& Gao, L. (2017). Does corporate social responsibility disclosure improve firm investment efficiency? Evidence from China. Review of Accounting and Finance, 16(3), 348-365. Retrieved from https://doi.org/10.1108/RAF-062016-0095 


\section{APPENDIX}

\begin{tabular}{|c|c|c|c|}
\hline \multicolumn{4}{|c|}{ Appendix 1 Population of NSE listed Oil and Gas firms in Nigeria } \\
\hline S/NO. & Company & Ticker & Date Listed \\
\hline 1 & 11 Plc. & MOBIL OIL & 1978 \\
\hline 2 & Anino International & ANINO OIL & Jan.2, 1990 \\
\hline 3 & Capital Oil Plc. & CAPOIL & August $11^{\text {th }}, 1989$ \\
\hline 4 & Conoil Plc. & CONOIL & 1989 \\
\hline 5 & Eterna Plc. & ETERNA OIL & March 8th, 1998 \\
\hline 6 & Forte Oil Plc. & FO OIL & 1978 \\
\hline 7 & Japaul Oil and Maritime Services Plc. & JAPAULOIL & August $10^{\text {th }}, 2005$ \\
\hline 8 & Mrs Oil Nigeria Plc. & MRS OIL & 1978 \\
\hline 9 & Oando Plc. & OANDO OIL & Feb.24th,1992 \\
\hline 10 & Rak Unity Petroleum Company Plc. & RAKUNITY & Nov.16th,1987 \\
\hline 11 & Seplat Petroleum Dev. Co.Plc (MPN) & SEPLAT OIL & April 14th,2014 \\
\hline 12 & Total Nigeria Plc. & TOTAL OIL & April 20th,1979 \\
\hline
\end{tabular}

Source: http://www.nse.com.ng/issuers/listed-securities/listed-companies and NSE Fact Book (2019).

\begin{tabular}{|ccc|}
\hline Appendix 2 Sample Size of the Study & \\
\hline S/NO. & Company & Ticker \\
\hline $\mathbf{1}$ & Eternal Plc. & OIL \\
\hline $\mathbf{2}$ & ARDOVA Oil & FORTE OIL \\
\hline $\mathbf{3}$ & 11 PLC & MOBIL OIL \\
\hline $\mathbf{4}$ & MRS Oil Nigeria Plc. & MRS OIL \\
\hline $\mathbf{5}$ & OANDO Plc. & OANDO OIL \\
\hline $\mathbf{6}$ & SEPLAT Petroleum Development Co. PLC & SEPLAT OIL \\
\hline $\mathbf{7}$ & TOTAL Nigeria Plc. & TOTAL OIL \\
\hline
\end{tabular}

Source: NSE Fact Book (2019)

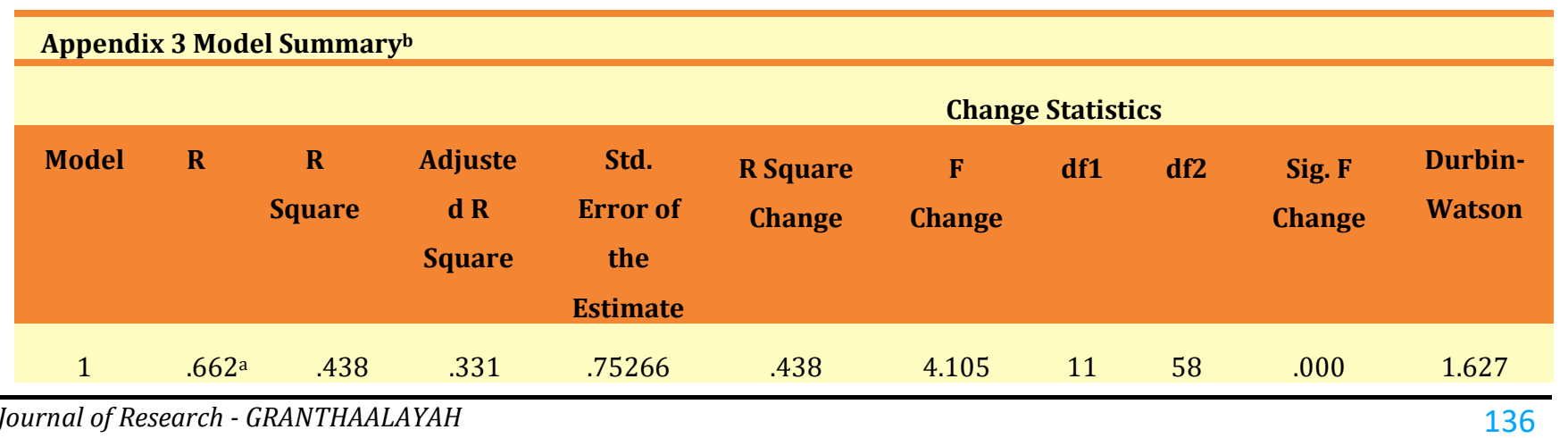


a. Predictors: (Constant), EPS, FG, FZ, CSREDE, CSRHE, ROA, CSREE, CSRSPE, CSRSE, CSRCDE, PBIT

b. Dependent Variable: NICF.

\begin{tabular}{|c|c|c|}
\hline \multicolumn{3}{|c|}{ Appendix 4 Test for Collinearity: Variable inflation Factor (VIF) } \\
\hline \multicolumn{3}{|c|}{ Coefficients $^{\mathrm{a}}$} \\
\hline \multicolumn{3}{|c|}{ Collinearity Statistics } \\
\hline Model & Tolerance & VIF \\
\hline CSRCDE & 0.525 & 1.905 \\
\hline CSREDE & 0.65 & 1.538 \\
\hline CSRSE & 0.483 & 2.072 \\
\hline CSRHE & 0.708 & 1.412 \\
\hline CSREE & 0.813 & 1.23 \\
\hline CSRSPE & 0.716 & 1.396 \\
\hline FZ & 0.926 & 1.08 \\
\hline $\mathrm{FG}$ & 0.781 & 1.281 \\
\hline PBIT & 0.465 & 2.153 \\
\hline ROA & 0.694 & 1.44 \\
\hline EPS & 0.655 & 1.526 \\
\hline
\end{tabular}

a. Dependent Variable: NICF

\begin{tabular}{|cccccc|}
\hline Appendix 5 ANOVAa & & & & & \\
\hline Model & Sum of Squares & Df & Mean Square & F & Sig. \\
\hline Regression & 25.579 & 11 & 2.325 & 4.105 & $.000^{\text {b }}$ \\
\hline Residual & 32.857 & 58 & 0.567 & & \\
\hline Total & 58.436 & 69 & & \\
\hline
\end{tabular}

a. Dependent Variable: NICF

b. Predictors: (Constant), EPS, FG, FZ, CSREDE, CSRHE, ROA, CSREE, CSRSPE, CSRSE, CSRCDE, PBIT 